\title{
Metallothionein Gene Expression in Drosophila subobscura Indicates Their Different Function in Response to Heavy Metal Exposures $^{\dagger}$
}

\author{
Mina Rakić 1,2, , Mihailo Jelić ${ }^{1}$, Marina Stamenković-Radak 1,2, Aleksandra Patenković ${ }^{2}$, Marija Tanasković ${ }^{2}$, Kata- \\ rina Erić ${ }^{2}$, Slobodan Davidović ${ }^{2}$, Pavle Erić ${ }^{2}$ and Marija Savić Veselinović ${ }^{1}$
}

Citation: Rakić, M.; Jelić, M.; Stamenković-Radak, M.; Patenković, A.; Tanasković, M.; Erić, K.; Davidović, S.; Erić, P.; Veselinović, M.S. Metallothionein Gene Expression in Drosophila subobscura Indicates Their Different Function in Response to Heavy Metal Exposures, in Proceedings of the 1st International Electronic Conference on Entomology, 1-15 July 2021, MDPI: Basel, Switzerland, doi:10.3390/IECE-10508 Published: 1 July 2021

Publisher's Note: MDPI stays neutral with regard to jurisdictional claims in published maps and institutional affiliations.

Copyright: (C) 2021 by the authors. Submitted for possible open access publication under the terms and conditions of the Creative Commons Attribution (CC BY) license (http://creativecommons.org/licenses /by/4.0/).
1 University of Belgrade, Faculty of Biology, Studentski trg 16, Serbia

2 University of Belgrade, Institute for Biological Research "Siniša Stanković", National Institute of Republic of

Serbia, Bulevar despota Stefana 142, Serbia

* Correspondence: b3015_2019@stud.bio.bg.ac.rs

+ Presented at the 1st International Electronic Conference on Entomology (IECE 2021), 1-15 July 2021; Available online: https://iece.sciforum.net/.

\begin{abstract}
Heavy metals are one of the most persistent pollutants that are introduced into the environment through human activity and ever so growing industrialization, exploitation and utilization of natural heavy metal deposits. Due to their toxicity, heavy metals have severely negative effects on organisms, mainly through oxidative stress. The objective of this research was to investigate the influence of heavy metals on the expression of six metallothionein genes $(M \operatorname{tn} A, B, C, D, E, F)$, with the intention to show to which extent the concentration of metals and the duration of the exposure influence $M t n$ gene expression, as well as the potential correlation of certain metallothioneins to a specific metal or combination of them. Larvae of the fruit fly Drosophila subobscura were subjected to the treatments with four heavy metals: zinc, copper, cadmium or lead. A combination of cadmium and lead was also included, to detect the combinatory effect of these metals. Treatment with each of the heavy metals was conducted in two concentrations, in short-term ( 24 hours) and longterm (10 days) time frame. Gene expression was analyzed with qPCR. The pattern of gene expression in response to various treatments indicates that some genes show specificity to certain metals, while others demonstrate a broader response or no response at all.
\end{abstract}

Keywords: Heavy metals; Metallothioneins; Drosophila subobscura 